\title{
PACKAGING TRAINING FOR TRADITIONAL EMPING MELINJO CRACKERS' PRODUCERS IN MENES VILLAGE, PANDEGLANG BANTEN
}

\author{
${ }^{1}$ Marta Sanjaya \\ Communications ProgramBina Nusantara University \\ Kemanggisan, Palmerah, Jakarta, Indonesia \\ fauza@binus.ac.id
}

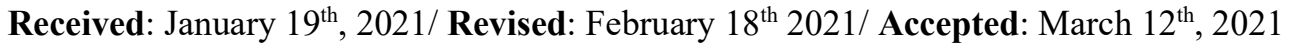

\begin{abstract}
Menes village in Pandeglang, Banten has long been known as the largest Emping Melinjo cracker producing area in Indonesia. The production process is carried out using a conventional process with family management, where each head of the family produces small to medium quantities of the cracker and then the middlemen or wholesalers collects them. The Emping producer's community has some limitation in packaging knowledge and technology that makes them receive only a small profit. We provide a material regarding the good packaging concept to improve the knowledge of community. In addition, the booklet material also equipped with various explanations about marketing strategies to help the community develop products and increase sales. After receiving the booklet material, some feedbacks from participants gathered to find the effectiveness of such method of knowledge delivering.
\end{abstract}

\section{Introduction}

Melinjo (Gnetum gnemon.L) is one of typical plant from Indonesia. Melinjo plant has long been used for various uses by the community. Melinjo as one Multi Purpose Tree Species (MPTS) plants are moderately resistant to fire hazard, because the tree branches are long and water content the stems are high enough, so that Melinjo is recommended to be planted to prevent forest fires [1]. It was also reported that the melinjo plant suitable to be developed for reforestation plants in critical lands or as a cover crop. Melinjo Stems have been used as building material, while it leaves and flowers consumed as vegetable. The Melinjo seeds, which research shows have anti-microbial properties and contain anti-oxidants that are beneficial to health [2], can be used as a raw material to produce Indonesian favored snack crackers called Emping. Emping has cracker shaped with slightly bitter taste. It not only sold in Indonesia but also other countries as export commodity, moreover it has high selling price.

Melinjo commonly produces in Java, one of the biggest producer comes from Pandeglang, Banten. Emping melinjo is also typical food from Pandeglang because the production provide high profit for the district [3]. Menes is one of the village from Pandeglang, Banten Province which known as the production village of Emping Melinjo Cracker. Based on statistical data from the Forestry and Plantation Service of Pandeglang District, average production from sub-district is 287,86 ton while Menes sub-district produces the biggest amount of 609,8 ton raw Emping Melinjo cracker [4].

The production process of Emping Melinjo cracker in Menes is carried out using a conventional process with family management, where each head of the family produces smallmedium quantities of the cracker and then collects them to middlemen or wholesalers. 
Emping's producer cannot develop their products independently because of their limited capabilities and limited mastery of technology. They either cannot pack their own product or sell their product to e-commerce platform because they don't know the basic concept of good and attractive packaging. This causes the producer community to receive only a small profit.

\section{Packaging for Emping Melinjo Cracker}

Knowing the limited knowledge of the Menes community about product's packaging, we planed to conduct a training to deliver knowledge in a workshop conducted at district office. Initially, we planed to deliver the basic concept and demonstrate the packaging process by bringing along a sample of packaging tools. We hope that the community will understands and can take advantage of the training results.

But, Due to COVID-19 pandemic that is happening around the world, we cannot carry out the training that gathers the crowds. We also had difficulty finding ways to convey material online to the Community. People in Menes are not familiar with video conferencing technology. In fact, many of them do not own smartphones. The only way to deliver the knowledge is by creating a booklet of material that serves information about packaging, including some images to give complete overview of packaging process.

Packaging is one way to protect or preserve food or non-food products. Packaging is a container or a place used to package a product, which is equipped with labels or descriptions including some of the benefits of the content packaging. Packaging has an important role and function in supporting product distribution especially those that are easily damaged.

In general, there are 4 functions of packaging:

1) As a container

Makes it easy to store solid products, starches, liquids, and gases from being scattered.

2) As protection

Packaging serves to protect products from the surrounding environment, such as avoiding physically, chemically and microbiologically contamination. Packaging design and materials that do not meet the requirements will reduce the quality of the packaged products.

3) Supporting storage and distribution methods

The products to be marketed are usually not brought directly from the factory to the retailer, but through a rather long marketing channel. Packaging must be made in such a way as to efficiently use space in storage or transportation.

4) Marketing

The first step in marketing a product is to attract the attention of consumers. This interesting way includes sticking something interesting on the packaging product, for example presentation suggestions, product form, and composition.

Based on the functions described above, we created a booklet material that contains various important points regarding the packaging process and sales of Emping Melinjo cracker.

1) Packaging for Emping Melinjo Cracker

In choosing the packaging material for chips products, some things to note are explained in the booklet as follows. First, consider the price. It is better to choose the materials that cost less. Then, the material should be resistant to heat or resistant to freezing temperatures, and the last it suggested that the packaging material can be seen clearly. 
Table 1. Packaging Materials Suggestion

\begin{tabular}{|c|c|c|}
\hline No. & Materials & Properties \\
\hline 1. & Foil & $\begin{array}{l}\text { Odorless, non-toxic, flexible, } \\
\text { heat resistant }\end{array}$ \\
\hline 2. & Polyethylene (PE) & $\begin{array}{l}\text { heat resistant, not frost resistant, } \\
\text { not oil resistant }\end{array}$ \\
\hline 3. & Polypropylene & $\begin{array}{l}\text { frost resistant, oil resistant, } \\
\text { not heat resistant }\end{array}$ \\
\hline
\end{tabular}

2) Food Label

A good food label shows some information about the products. A small business should pay attention to some criteria. Food label should provide product information in fact. The photo or image does not appear consumer confusion. Producer Identity is also put on the label. It could be a logo, or the image of the product itself. The last, food label should give the information of product weight.

(a)



(b)

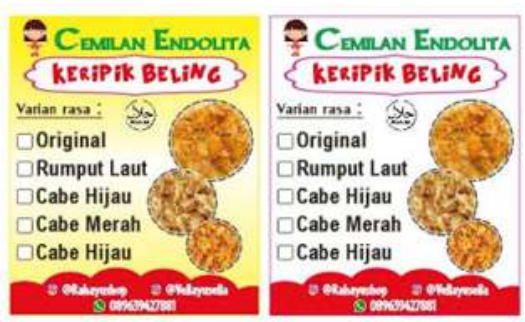

Fig. 1 (a) Printed food label on packaging, (b) Printed sticker food label

\section{3) Marketing Strategies}

Emping is a traditional Indonesian food processed similar to crackers with the basic ingredient of melinjo seeds. Currently, many areas have become centers for the production of melinjo chips because they are very popular with the public as a snack or complement to various Indonesian foods. It has become a habit for Indonesian people, if you eat without being accompanied by crackers or chips, you feel like something is missing

To improve the sales, producers should not focus only on producing process. Marketing strategies are important to improve the sales. Producers should know and understand the target consumer. By knowing the characteristics of the consumer, producers can producers can develop product's variations. In addition, paying attention to product quality such as shape, hygiene standards and product preservation, are marketing strategies that can increase sales.

\section{Training Material Distribution}

As a result of the COVID-19 pandemic, packaging training materials for the cracker producer community Emping Melinjo in Menes Village were distributed conventionally by sending booklet materials. We submitted the booklet beforehand to village officials, through Carik Mr. Muhidin in the village (0822-1399-3939) and Pak Eman Village Assistant (0812-7002-2229), 
where previously they had determined which participants would receive training. Table 2 shows the knowledge transfer flow, after receiving the booklet material they read and learning how to technically make the melinjo crackers they produce that are popular and recognized. The material they read and studied is in the hope that the team can explain face-to-face and hold a meeting as the next step after Covid 19 is over and can be overcome. The material we send is packaged in such a way that it can be understood by the people of Menes Village, with the aim that the efforts and efforts of the Melinjo cracker entrepreneurs in Menes Village to improve their daily needs for the better. Emping Melinjo entrepreneurs in Menes Village reside in several hamlets around Menes Village, which are quite far from one hamlet to another, with a fairly difficult reach, especially the presence of technology, related to the marketing of these products, so with this training it is hoped that in the future Bina Nusantara University can help overcome these problems.

Table 2 The knowledge transfer flow

\begin{tabular}{|c|c|c|c|}
\hline first step & second step & third step & fourth step \\
\hline $\begin{array}{c}\text { - delivery } \\
\text { material } \\
\text { booklets }\end{array}$ & $\begin{array}{l}\text { - the village } \\
\text { official } \\
\text { received } \\
\text { material } \\
\text { booklets } \\
\text {-the village } \\
\text { officials } \\
\text { studied } \\
\text { material } \\
\text { booklets }\end{array}$ & $\begin{array}{l}\text { - the village } \\
\text { official } \\
\text { gathered } \\
\text { together the } \\
\text { cracker } \\
\text { producers to } \\
\text { explain } \\
\text { material } \\
\text { booklets } \\
\text { (about } 10 \\
\text { participans), } \\
\text { with regard } \\
\text { to health } \\
\text { protocols }\end{array}$ & $\begin{array}{l}\text { - the cracker } \\
\text { producers } \\
\text { practicing } \\
\text { the material } \\
\text { trainning. } \\
\text { - for about a } \\
\text { few weeks } \\
\text { the village } \\
\text { officials } \\
\text { evaluated } \\
\text { the results } \\
\text { - the village } \\
\text { official gave } \\
\text { us the } \\
\text { results of the } \\
\text { evaluation }\end{array}$ \\
\hline
\end{tabular}

\section{People's Feedback and Evaluation}

Community Service Training Activities related to the Melinjo chips business in Menes village, Menes village emping entrepreneurs really hope this training can add knowledge related to packaging and peckejing, so that the quality and quality of production that is of interest can be known by outsiders. This training activity is not only temporary but can also be repeated in the future, especially by establishing good cooperation in fostering emping entrepreneurs in Menes village.

Suggestion :

- That it is necessary to improve the quality of business products to collaborate with several agencies, especially universities.

- In marketing products, there should be a synergy between outsiders who can bridge the products so that they can be recognized and attracted by outsiders. 


\section{Conclusion}

Emping is a traditional Indonesian food processed similar to crackers with the basic ingredient of melinjo seeds. Currently, many areas have become centers for the production of melinjo chips because they are very popular with the public as a snack or complement to various Indonesian foods. It has become a habit for Indonesian people, if you eat without being accompanied by crackers or chips, you feel like something is missing.

One of the well-known centers for making chips is in Banten Province, namely in Menes District and Cikedal District, Pandeglang Regency.

Emping Menes is famous and much sought after because of its distinctive taste. The taste of melinjo is savory and slightly bitter combined with the aroma of smoke

\section{References}

[1]. Otsuka M, Sumantri, Kuspriyadi, Syaharudin. Review of the Participatory Forest Fire Prevention Programs in Jambi and West Kalimantan, Indonesia. In Communities in Flames. In International Conference on Community Involvement in Fire Management.; 2002.

[2]. Yanti L. The Potential and Development Opportunities of Processing Technology of Melinjo in Supporting of Food Security in Jambi Province. Balai Pengkajian Teknologi Pertanian Jambi. 2013.

[3]. Iqbal Z, Dewi NS, Nugraha A, Syuaib MF. DEVELOPMENT OF MELIJO PEELING MACHINE AS AN INNOVATIVE SOLUTION FOR SMALL-MEDIUM SCALE AGROINDUSTRY OF MELINJO (Gnetum gnemon L.). In The 1st Annual International Scholars Conference in Taiwan; 2013. p. 529-534.

[4]. Aliudin, Angraeni D. Added Value Melinjo Chip with Conventional Production in Menes Village. AGRIKA. 2012; 6. 